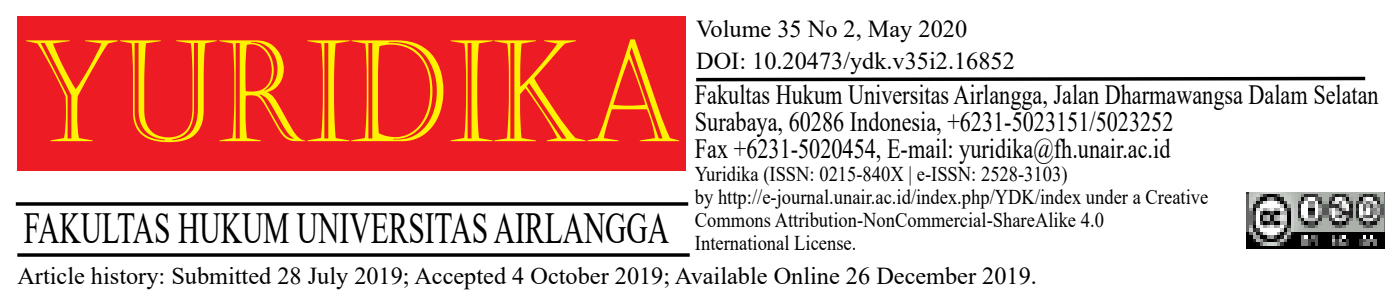

\title{
The Concept of Conspiring to Corrupt in Criminal Law as Ius Contituendum
}

\author{
Yulianto \\ Yulianto_1969@yahoo.com \\ High Attorney of West Sumatra
}

\begin{abstract}
The term conspiring to commit criminal acts in Article 15 of PTPK Act cannot refer to existing norms under Article 88 of the KUHP. The criminal act which is to conspire to commit such acts within PTPK Act has been regulated within the Indonesian legal system and recognized by law enforcers. However, the lack of elaboration and clarity towards this type of criminal act in the PTPK Law has hindered law enforcers from utilizing Article 15 of the PTPK Act to combat corruption. The Constitutional Court has attempted to resolve the legal uncertainty of Article 15 of the PTPK Act, however this has been proven to become burdensome for law enforcers in applying the criminal justifications of conspiracy under the scope of Article 15 of the PTPK Act. The criminal act which is to conspire to commit such acts within PTPK Act has been regulated within the Indonesian legal system and recognized by law enforcers. Keywords: Corruption; Bad Conspiracy; Ius Constitutedum.
\end{abstract}

\section{Introduction}

The state aims to desire order in society. ${ }^{1}$ Corruption is not only detrimental to the country's finances but violates social norms. ${ }^{2}$ when discussing the eradication of corruption, it will focus on three main issues, namely: prevention, eradication, and return of assets. ${ }^{3}$ Charges based on the grounds of conspiracy in corruption has been conducted in the practice of Indonesia's judiciary, namely within the case of Anggodo Wijoyo and Ary Muladi that has committed criminal conspiracy towards

1 Sudikno Mertokusumo, 'Sistem Peradilan Di Indonesia' (1997) 6 Jurnal Hukum Ius Quia Iustum <https://journal.uii.ac.id/IUSTUM/article/view/6927>.[1].

2 Rudy Hendra Pakpahan and Aras Firdaus, 'Pembaharuan Kebijakan Hukum Asset Recovery: Antara Ius Constitutum Dan Ius Constituendum' (2019) 16 Jurnal Legislasi Indonesia <http://ejurnal.peraturan.go.id/index.php/jli/article/view/514>.[369].

3 Tari Endah Guntari and Rizanizarli, 'Penerapan Uang Pengganti Sebagai Pidana Tambahan Terhadap Terpidana Korupsi’ (2017) 1 Jurnal Ilmiah Mahasiswa Bidang Hukum Pidana, Fakultas Hukum Universitas Syiah Kuala.[115]. 
the handing over of funds for investigators and leaders of the KPK in regards to the legal process of Anggoro Wijoyo and PT. Masaro Radiokom. Syahril Djohan has also been charged for criminal conspiracy with Haposan Hutagalung in the case of Arowana. The public prosecutor charged Syahril Djohan with the primary charge of Article 5 paragraph (1) letter a of Law Number 31 of the Year 1999 regarding the Eradication of Corruption (State Gazette of the Republic of Indonesia year 1999 Number 140, Additional State Gazette Number 3874) and Law Number 20 of the Year 2001 regarding the changes to Law Number 31 of the Year 1999 regarding the Eradication of Corruption (State Gazette of the Republic of Indonesia Year 2001 Number 134, Additional State Gazette of the Republic of Indonesia Number 4150) hereinafter "PTPK Act jo. Article 55 paragraph (1) Number-1 of the KUHP, Subsidair Article 13 of PTPK Act jo. Article 55 paragraph (1) Number-1 KUHP and the second charge, primary: violating Article 5 paragraph (1) letter a jo. Article 15 of PTPK Act jo. Article 88 KUHP and subsidiary Article 13 jo. Article 15 of PTPK Act jo. Article 88 KUHP. The public prosecutor in its charge stated that the defendant Syahril Djohan is guilty of committing criminal conspiracy such as that elaborated within the primary and subsidiary charges. However, the judge has a different opinion regarding such issues and argues that the meetings were conducted within the capacity of the defendant and there further action is not enough to present a claim of criminal conspiracy.

The term criminal conspiracy in Article 15 of the PTPK Act cannot refer to the norms within Article 88 of KUHP. The criminal act which is to conspire to commit such acts within PTPK Act has been regulated within the Indonesian legal system and recognized by law enforcers. However, the lack of elaboration and clarity towards this type of criminal act in the PTPK Law has hindered law enforcers from utilizing Article 15 of the PTPK Act to combat corruption. The Constitutional Court has attempted to resolve this issue of legal uncertainty within Article 15 of PTPK Act regarding criminal conspiracy, however in its application it has provided more burden towards law enforcers in implementing such criteria rendered within Article 15 of the PTPK Act. 
The Constitutional Court decision Number 21/PUU-XIV/2016, has provided a verdic which states that the phrase criminal conspiracy within Article 15 of the PTPK Act contradicts the 1945 Indonesian Constitution as long at is does not have meaning, criminal conspiracy is when two or more persons that have similar qualifications conspire together to commit a criminal act. In principle, the formulation of criminal conspiracy in the KUHP is similar to that within the aforementioned constitutional court decision. However, the constitutional court added a new element that is two or more people with similar qualifications. With this new formulation regarding the concept of criminal conspiracy within Article 15 of the PTPK Act, then it must be proven that there exists an agreement and such agreement must be made by people with the same qualifications. The constitutional court decision which creates a new formulation in the criminal act of criminal conspiracy in corruption has brought forward new legal problems relating to the phrases "same qualifications". The constitutional court did not provide further understanding and concept on qualifications in conducting corruption, for instance with regards to whether or not these persons uphold the same authority or have the same economical powers. This lack of clarity has presented an element of ambiguity in the new norms regarding criminal conspiracy for acts of corruption. Based on the aforementioned introduction, the research question discussed will be the concept of criminal conspiracy as a ius constitendum.

\section{The Criminal Conspiracy in Indonesian Criminal Law}

The criminal conspiracy mentioned within Article 15 of the PTPK Act jo. Constitutional Court Decision Number 21/PUU-XIV/2016 is that every person that has attempted, aided, supported or conspire to commit a corruption in accordance with the provisions in Article 2, Article 3, Article 5 until Article 14, can be charged with a criminal charge within the meaning of Article 2, Article 3, Article 5 until Article 14. The formulation of criminal conspiracy within the Constitutional Court decision Number 21/PUU-XIV/2016 has presented several legal issues due to the new requirements of two or more persons that have agreed and have the same qualities. 
The Constitutional Court has stated that there cannot be criminal conspiracy for qualitative delict where two or more persons that have the same quality have agreed to commit a crime. Criminal conspiracy that is mentioned within Article 15 of PTPK Act has clearly committed corruptive acts and, as a result, the constitutional court should provide a elaboration on the additional requirements. If the meaning of same qualifications within the context of committing a criminal conspiracy refers to the authority or occupational position, then this clearly limits the scope of the definition for criminal conspiracy in the criminal act of corruption. There also exists another argumentation which states that the limitation of criminal conspiracy for criminal acts are those committed by civil servants of the State that retains the authority and occupational positions. In this case, there exists no possibility for civil servants of the State to commit such criminal conspiracy with persons of private entities that have interests. If the concept of criminal conspiracy in the criminal act of corruption is limited to the qualities of the people committing the acts, then this legal norm cannot be applied to prevent criminal conspiracy between individuals who do not have the same qualifications. The holder of authority or position has the qualifications to force private parties by utilizing the interests of the private party. In these cases, the private party does not have the freedom to refuse the request of the authority holder because the interests of the private party are dependent on those with authority or significant occupational positions. In other words, one party has the authority whereas the other party has no authority at all.

Criminal conspiracy in Indonesian criminal law has been present ever since the enactment of the KUHP through the concordance principle from the Dutch. Criminal conspiracy, as mentioned within Article 88 of the KUHP, is when two or more persons have agreed to commit a criminal act. The act of criminal conspiracy in the Indonesian criminal law system has been regulated in several legislations. Based on these existing observations, there exists several legislations in Indonesia that regulates criminal conspiracy namely the KUHP, the Narcotics Act, Law Number 5 of the Year 1997 regarding Psychotropic (State Gazette of the Republic of Indonesia Year 1997 Number 10, Additional State Gazette of 
the Republic of Indonesia Number 3671) as well as several existing legislations. Criminal conspiracy in the Narcotics Act has is a the act of two persons or more that have agreed to conduct, executed, participated, directed, suggested, facilitate, consulter, become a member of an organized drugs organization or organized a criminal narcotics act. The concept of criminal conspiracy in the Narcotics Act is different from the concept of criminal conspiracy in the KUHP and other existing legislations, due to the fact that the Narcotics Act broadens the meaning of criminal conspiracy and includes the participation in an organized crime. Whereas within the KUHP and other specific legislations, the concept of criminal conspiracy is limited to only participation.

In principle, the concept of criminal conspiracy relates to the concept of participation due to the fact that criminal conspiracy requires the existence of an agreement between two persons or more. The requirement of 'two persons or more' is also one of the requirements pertained within Article 55 of the KUHP. There exist several types of perpetrators according to Article 55 of the KUHP, which are:

a) Those who commit criminal acts. Those who commit criminal acts have the understanding that they are the person who are the main perpetrators.

b) Those who direct other persons to commit criminal acts. This type of perpetrator are those who move others with specific reasoning to commit a criminal act. The perpetrators has the will to commit but he/she does not want to single-handedly commit the criminal act.

c) Those who participate in a criminal act. This type of persons are usually more than one. They together commit the criminal act and retain full-responsibility.

d) Those who suggest to commit a criminal act.

The construct of criminal law has clearly regulate deelneming, stating that within such delict there exists a difference in capacities of a perpetrator to three categories, such as those mentioned in Article 55 paragraph (1) Number-1 of the KUHP. The doctrine of inclusion does require that there is an affirmation of the capacity or position of the perpetrators who participated in committing a crime. Unlike the case in the concepts of agreement that does not regulate the distribution of roles or positions of the actors who made the agreement. In the development of criminal law, especially based on the theory of the separation of criminal acts and criminal liability, participation is no longer seen as an extension of criminal liability 
as currently held but is placed within the scope of the expansion of criminal acts. ${ }^{4}$ The doctrine of inclusion as an extension of a criminal offense must still be tested because the criminal offense of inclusion is not a criminal offense such as that of criminal conspiracy to commit a particular crime. Throughout the history of the formation of legislation in Indonesia, there is not a single law that regulates the criminal act of inclusion because the nature of the inclusion is to expand criminal liability. The inclusion does not give birth to a new crime or another because in the inclusion of a criminal offense committed by one but carried out by several perpetrators of the crime so that the position of the perpetrators is confirmed through the teaching of inclusion.

The doctrine of inclusion has similarities with the act of criminal conspiracy but in principle it is different. Malicious agreements to commit certain criminal acts are an extension of criminal liability and criminal offenses. The expansion of criminal liability in evil consensus appears in the conditions of evil consensus when two or more people agree to commit a crime. The expansion of criminal acts is seen in the criminal provisions, namely in the Criminal Code and special laws regulating criminal agreements to commit criminal acts as referred to in the relevant criminal rules so that criminal acts of criminal agreement stand alone and have their own characteristics from the main criminal acts. The basic criminal provisions apply if the criminal act has been completed or all the elements required in the criminal act are fulfilled while in regards to criminal agreements it does not require the completion of the criminal act.

Criminal conspiracy do not apply to all criminal acts but are limited to certain criminal acts which are extremely dangerous so that prevention is prioritized over eradication. Bad consensus in Article 13 of the Criminal Code Bill is an evil consensus that occurs if 2 (two) or more people agree to commit a crime. A criminal agreement for a criminal offense commits a crime of at most $1 / 3$ (one-third) of

\footnotetext{
4 Muhammad Ainul Syamsu, Pergeseran Turut Serta Melakukan Dalam Ajaran Penyertaan, Telaah Kritis Berdasarkan Teori Pemisahan Tindak Pidana Dan Pertanggungjawaban Pidana (Pertama, Kencana Prenada 2014).[92].
} 
the maximum principal criminal threat for the relevant crime. Furthermore, in the Elucidation of Article 13 of the RUU KUHP explains the agreement to commit a criminal offense is only subject to a criminal offense for a very serious crime, for example, criminal acts against state ideology, treason, sabotage, criminal offenses during war, criminal acts of corruption, criminal acts of money laundering, and criminal acts of terrorism.

Article 617 of the RUU KUHP in the Meeting of September 2019 regulates the provisions regarding criminal conspiracy, preparation, attempt and aiding that is regulated in the law regarding heavy crimes towards human rights, terrorism, corruption, money laundering and narcotics, based on existing regulations. Based on Article 617 of the RUU KUHP Meeting of September 2019, the regulations within Article 15 of the PTPK Act is still valid, however the provisions regarding corruption will be regulated by the RUU KUHP. Furthermore, Article 626 paragraph (1) letter e of the RUU KUHP Meeting Results of September 2019 regulates that when the law is enacted, Article 2 paragraph (1), Article 3, Article 5, Article 11, Article 13 and Article 15 of the PTPK Act will be revoked and remain invalid. When looking at Article 626 paragraph (1) letter e of the RUU KUHP Meeting of September 2019, the act of criminal conspiracy in the context of corruption regulated in the PTPK Act will no longer remain valid after the enactment of the RUU KUHP. Thus, the provisions within Article 617 of the RUU KUHP Meeting of September 2019 will go against Article 626 paragraph (1) letter e of the RUU KUHP Meeting of September 2019 which will lead to legal uncertainty.

Furthermore, if the provisions of Article 617 RUU KUHP Meeting of September 2019 are deemed binding, then the application of Article 15 of PTPK Act will arises legal problems because based on Article 626 paragraph (4) of RUU KUHP Meeting of September 2019, the requirements of corruption refers to the provisions of Article 2 and the referral will be altered by Article 605; Article 3 will be replaced with Article 608 paragraph (2). Thus, Article 15 of the PTPK Act can be implemented fully because corruption, as asserted in Article 2,3,5,11 and Article 13 has already been taken over by KUHP. Thus, Articles 2,3,4,11 and Article 13 that is 
mentioned in Article 15 of the PTPK Act will no longer be valid. Furthermore, within RUU KUHP Meeting of September 2019 does not regulate criminal conspiracy for corruption. Thus, Article 15 of PTPK Law will enact 2 different implementations for the act of corruption.

Aside from that, the reasoning for criminal conspiracy in the act of corruption is based on the consideration that the efforts to prevent and combat corruption is the one of the ways to prevent a loss for a State's economy. With the provisions of the RUU KUHP Meeting of September 2019 that does not regulate criminal sanctions regarding criminal conspiracy in the act of corruption, the implementation of existing provisions with extraordinary efforts to prevent and combat corruption is no longer relevant. RUU KUHP Meeting of September 2019 that provides that the status of corruption as an extraordinary crime denies the detrimental effects of corruption in the Indonesian legal system which is concerning.

The policies regulating criminal law within the RUU KUHP contradicts the existence of the KPK, still remains prevalent today. If the government and DPR have concluded that corruption is not an extraordinary crime, then the existence of the KPK is no longer necessary. However, legislators still retain the existence of the KPK which means that corruption is still an extraordinary crime. If the act of corruption is still an extraordinary crime, then the criminal law policies regarding the criminalization of criminal conspiracy is still relevant and must be maintained to optimize the prevention efforts for corruption by utilizing criminal sanctions as a primum remidium or the first and main means.

Preventing corruption in Indonesia has been misused because the prevention in defined as putting aside the prosecution. Law enforcers, especially the KPK, has remained neglectful because the PTPK Act provides an opportunity for law enforcers to conduct preventive measures against corruption through the criminal sanction approach. This criminal sanction approach will contain the understanding that law enforcers must enforce criminal law. The preventive actions against corruption with this criminal sanction approach engraved in Article 15 of the PTPK Act that regulates criminal conspiracy regarding corruption, as written in Articles 
2,3, and Article 5 - 14 of the PTPK Act. Being able to charge two or more persons who have agreed to commit corruption, as regulated within articles 2,3 and Article $5-14$ of the PTPK Act is a preventive measure against corruption.

Article 15 of the PTPK Act is an opportunity for law enforcers to prevent double loss of the State, in the sense that if the criminal act of corruption has occurred, the financial loss suffered by the State may not be able to be fully compensated and the prosecution of these perpetrators will also burden the State financially. When the prevention for the acts of corruption is conducted through a criminal conspiracy regime, as such regulated within Article 15 of the PTPK Act, then the financial loss suffered by the State will only be done during the prosecution process. Thus, in the optimal application of Article 15 of the PTPK Law in regards to the prevention of corruption must firstly be based on the correct drafting of the law itself that is stated clearly, paying due regard to the elements of legal certainty and justice. Criminal law does reduce the rights that is justified but this does not mean that it can abandon the principles which render a person guilty. Provisions must ensure that it upholds restitution, not to worsen a situation. ${ }^{5}$

The formulation of criminal conspiracy in the sense of Article 15 of the PTPK Law must be clearly formulated as an ius constituendum or law envisioned in the context of preventing corruption. This is in line with Machteld Boot, which cites the opinion of Weigend and Jesheck, who stated the principle of legality contains four meanings, namely nullum crimen nulla poena sine lege praevia (no criminal acts without previous law), nullum crimen nulla poena sine lege scripta (no criminal without written law), nullum crimen nulla poena sine lege certa (there is no criminal act without a clear law) and nullum crimen nulla poena sine lege stricta (no criminal without strict laws). The formulation of criminal conspiracy in a criminal act of corruption must refer to the principles of criminal responsibility in order to create legal certainty and justice. The translating team of the KUHP of the Body for Regulating National Law (hereinafter "BPHN") states that a criminal act (actus 
reus) must be differentiated and separated from criminal responsibility (mens rea) ${ }^{6}$ Utrecht states that a person can be prosecuted based on the existence of an act which contradicts the law, a person who is responsible over it and a person who's actions violate the law.

According to Romli Atmasasmita, the understanding of responsibility in criminal law is responsibility towards criminal acts or towards the results of such criminal acts. ${ }^{7}$ Simons elaborated that srafbaar feit is the act that is threaten with crime, that contradicts the law in nature and relates to the mistake that is done by the person holding responsibility. Satochid Kartanegara states that what is meant by strafbaar feit is a violation or breach of legal interest (schending of kreenking van een rechtsbelang), violation or the breach of legal interest (schending of kreenking van een rechtsbelang) and something that endangers legal interest (het in gevearbrengen van een rechtsbelang). ${ }^{8}$ Utrecht that interprets strafbaar feit as one of the actions that contradicts the law; a wrongful violations; an act that is within an existing law. ${ }^{9}$ Moeljatno elaborates that a criminal act is something that is prohibited by the law and is attached by threat (sanction), for those who violate such prohibitions. ${ }^{10}$ There also exists an element or principle of criminal law in which the action and consequence; initial element or situation that is attached to the act; additional circumstances that burdens the crime; objective elements of criminal violations; subjective elements of criminal sanctions. ${ }^{11}$

The criminal act that refers to the existence of a prohibition or threat of crime regarding an act that can be held criminally responsible towards a person must

6 Romli Atmasasmita, Rekonstruksi Asas Tiada Pidana Tanpa Kesalahan (Geen Straft Zonder Schuld) (Gramedia Pustaka Utama 2017).[26]. In Departemen Kehakiman RI, Kitab Undang-Undang Hukum Pidana Terjemahan Resmi Dari Wetboek van Strafrecht (WvS) (Sinar Harapan 1983).[10].

7 Romli Atmasasmita (n 6).[183].

8 Satochid Kartanegara, Hukum Pidana Kumpulan-Kumpulan Kuliah, Balai Lektur Mahasiswa, (Balai Lektur Mahasiswa 1998).[79].

9 E. Utrecht, Rangkaian Seri Kuliah Hukum Pidana I "Suatu Pengantar Hukum Pidana Untuk Tingkat Pelajaran Sarjana Muda Hukum Suatu Pembahasan Pelajaran Hukum (Universitas Padjajaran 1958).[252].

${ }^{10}$ Moeljatno, Asas-Asas Hukum Pidana (Rineka Cipta 2008).[59].

11 ibid.[69]. 
pay due regard to the mistakes that is attached to the perpetrator. ${ }^{12}$ The criminal responsibility must pay due regard to the mistakes and the legal principles (geen straft zonder schuld; actus non facit reum nisi mens sist rea) as one of the essential principles of a prosecution in deciding which sanctions cannot be enacted. Criminal responsibility must pay due regard to the actions of the perpetrators and the conditions of the perpetrators, to invoke the principle of legality and to be asserted in the principle of fault. ${ }^{13}$ The legality principle that is the basis for limiting state authority in invoking a criminal sanction and if the state or government wants to implement such sanctions, there must exists a legal regime first and foremost.

Meolijatno in his book the principles of criminal law asserts that in invoking a crime, the principles and existence of breach of legislations must be clear. The legality principle (nullum delictum nulla poena sine praevia lege) that is formulated by von Feuerbach is the fundamentals that the act that is categorized as a criminal act must be formulated in a legislation. The status of the principle of legality in providing a criminal charge is one of the legal protection that is given to the people and asserts that existing legislations must contain main elements. Schaffmeister, Keijzer and Sutorius elaborates that the principle of legality is an act that cannot be criminalized except under the basis of an existing rule of law; there exists no implementation of the law based on analogies; there exists no criminal charge based on habit/customs; there must be no formulation of a delict without clear purpose; no retroactivity of criminal legislations; there exists no criminal charge falling outside an existing legislation; and a criminal charge must be based on the methods established by law. ${ }^{14}$ The legality principle is a principle that cannot be deviated by law because it relates to the legal certainty and criminal sanctions. Thus, its provisions must be clear and strictly established by law. This is the reason why many reject the existence of Article 2 of the RUU KUHP Meeting Results

\footnotetext{
12 ibid.[165].

13 Roeslan Saleh, Perbuatan Pidana Dan Pertanggung Jawaban Pidana (Centra 1968).[28].

${ }^{14} \mathrm{~N}$ Keijzer dan E PH Sutorius D. Schaffmeister, Hukum Pidana (ketiga, Citra Aditya Bakti 2011).[7] terjemahan J.E. Sahetapy dan Agustinus Pohan.
} 
of September 2019, which in its main point regulates the legality principle and asserts the existence of basic societal rules that can govern criminal acts regardless of it being regulated in an official regulation. This principle of legality retains 3 understandings, such as: ${ }^{15}$

a) An act that is prohibited or is a criminal threat or is not regulated in an existing regulation;

b) To determine the existence of a criminal act, analogies must not be use;

c) No retroactivity.

\section{The Principle of Legality in Criminal Law}

The principle of legality is needed to oversight the implementation of special rights of the State in presenting a criminal charge towards a certain criminal act. If the criminal act contains a heavy sanction based on the societal rules of the people, then the criminal sanctions can be determined based on a majority vote. The principle of legality is a requirement for providing a charge because if an act does not qualify as a criminal act than the other requirements will not be fulfilled. There exist 2 different opinions regarding the requirements for providing a charge, which is that the act may not be separated from the perpetrator or in other words the person who commits a wrongful act can be charged for his/her actions. ${ }^{16}$ This monistic interpretation elaborates that criminal acts and criminal responsibility is one union whereas the dualistic interpretation views criminal acts and criminal responsibility as two separate issues due to the fact that a criminal act may sometimes not be held accountable to the perpetrators. The second interpretation that separates criminal liability from criminal acts and criminal experts from Indonesia who adhere to the separation of criminal liability from criminal offenses is Moeljatno, A.Z. Abidin and Roeslan Saleh. A.Z. Abidin argued that the monistic view held by the majority of legal scholars can lead to injustice and put criminal conditions into two parts namely actus reus (delictum) criminal acts

\footnotetext{
${ }_{15}$ Moeljatno (n 10).Op.Cit.[27-28].

16 E. Utrecht, Rangkaian Sari Kuliah Hukum Pidana I (Penerbitan Universitas 1958).[252].
} 
as conditions of objective punishment and mens rea-criminal responsibility as a condition of subjective punishment. ${ }^{17}$

If someone commits a crime, the criminal law will automatically be applied to that person with the principle that every mistake deserves punishment. While the second opinion states that an action carried out intentionally or not by someone who can be accounted for his actions and the law states that the act can be punished. ${ }^{18}$ Based on the aforementioned elaboration, it is concluded that the conditions in the punishment are threatened with criminal sanctions by law, contrary to the interests of the law, carried out by the person who is guilty and that person is deemed responsible for his actions. ${ }^{19}$ The above conditions are a combination of the principles of legality, wrongdoing and the ability to be responsible for criminal offenses. There is an opinion that states that there are 2 criminal conditions, namely criminal acts as a condition for objective punishment and criminal liability as a condition for subjective punishment. ${ }^{20}$ Hamzah Hatrik refers to the opinion of Sudarto which elaborates that there exists several requirements for criminal responsibility, such as: ${ }^{21}$

a. There exists a criminal act committed by the perpetrator;

b. There exists an element of fault whether it be commission or omission;

c. There exists someone that can be held responsible;

d. No exceptions.

If the four conditions above are fulfilled then the perpetrators of the crime are found guilty or have the ability to be responsible, then the perpetrators can be sentenced to criminal conviction. The first requirement relates to the principle of legality as explained earlier, that the crime must be regulated in statutory regulations. In addition to the principle of legality, a fundamental element in criminal liability is the fault of the perpetrator. Wilson ${ }^{22}$ said the teachings of no criminal without error can be translated as "an act is not criminal in the absence of a guilty mind". Kadish

\footnotetext{
${ }^{17}$ A.Z. Abidin, Asas-Asas Hukum Pidana Bagian Pertama (Alumni 1987).[259-260].

18 ibid.[255].

19 ibid.[256].

20 ibid.[259-260]

${ }^{21}$ Hamzah Hatrik, Asas Pertanggungjawaban Pidana Korporasi Dalam Hukum Pidana Indonesia (Strict Liability Dan Vicarious Liability) (Raja Grafindo Persada 1996).[12].

22 William Wilson, Criminal Law, Doctrine and Theory (Logman 2003).[67].
} 
and Paulsen ${ }^{23}$ translates: no criminal without error as "an unwarrantable act without a vicious will is no crime at all". Some of the views mentioned above confirm that in criminal law, mens rea is a necessity that must be met in criminal liability. Sudarto argued that a person's conviction is not enough if the person has committed an act that is contrary to the law or is against the law and for punishment there is still a need for conditions, that the person who committed the act has an error or is guilty. In other words, the person must be held responsible for his actions or if viewed from the point of his actions, his actions can only be accounted for by that person. ${ }^{24}$ Simons pointed out the error is the existence of certain psychic conditions in people who commit criminal acts and the relationship between these conditions with the actions carried out in such a way that the person can be denounced for doing the act earlier. ${ }^{25}$

Moelijatno stated that commission is knowledge that is the relationship between the defendant's mind or intellect and the actions carried out, so based on this, intentions are of two features namely intentionality as certainty and intentionality as a possibility. ${ }^{26}$ Furthermore, the act of commission means that there is a relationship between the act and the defendant's volition or volition, it cannot be called a separate fit besides the two features mentioned above because of the intended action or intended. Intentions must be based on the existence of a match between the will and the consequences of their actions, while intentionality with possibility is a condition in which the criminal acts committed by the perpetrators of crime are not in accordance with their intentions.

For example in a murder using food poison where it is very likely to be consumed by other people so that in the event that someone else dies due to food that has been poisoned, the perpetrator can still be convicted on the basis of intent.

\footnotetext{
${ }^{23}$ Stanford H. Kadish and Monrad G. Paulsen, Criminal Law and Its Process, Cases, and Materials (Toronto, Little Brown and Company 1975).[87].

${ }^{24}$ Sudarto, Hukum Pidana I, Badan Penyediaan Bahan-Bahan Kuliah FH-UNDIP (Universitas Diponegoro).[85].

${ }^{25}$ Romli Atmasasmita (n 6).[142].

${ }^{26}$ Moeljatno (n 10).[191-192].
} 
The possibilities that occur in a criminal offense by a criminal offense are a form of deliberation based on the existence of consequences other than the original purpose of the crime. Based on some of the opinions above, it can be concluded intentionality is divided into 3 forms, among others: ${ }^{27}$

a) Intent with means;

b) Intent with certainty;

c) Intent with high possibility of occurrence.

In addition to intentionality, another form of error in a criminal offense is negligence (culpa) by a criminal offender. Hazewinkel-Suringa argues that the crime of negligence (culpa) is a false offense (quasidelict) so that criminal reduction is held or known as per infortunium the killing occurred accidently or those who commit criminal acts of negligence are people who do not use their abilities that should be used. ${ }^{28}$ Van Toelichting's memory explains that negligence lies between intentional and accidental with the certainty that negligence is lighter than intentional. Criminal threats for criminal offenses in the form of errors in the form of negligence are lighter than intentional. Negligence is punished because everyone is required to be careful, alert and not careless so that it can prevent criminal acts. Negligence is not entirely due to the mistakes of the perpetrators because in certain circumstances the mistakes of the victims that triggered the crime but the mistakes of the victims are considered. However, the mistakes of the victims cannot be a reason to free the perpetrator of a criminal charge. This aligns with the Supreme Court Decision no. $354 \mathrm{~K} / \mathrm{Kr} / 1980$ and decision Number $205 \mathrm{~K} / \mathrm{Kr} / 1980$ which states that the mistakes of the victim does not eradicate a criminal charge. Van Hammel divides negligence into two things, which are:

a) Negligence because of inability to anticipate results;

b) Negligence due to a lack of carefulness.

Vos has a different view with van Hammel regarding the division of negligence in which Vos considers inadvertence to arise due to lack of looking forward. So it can

\footnotetext{
${ }^{27}$ Andi Hamzah, Hukum Acara Pidana Indonesia (Sinar Grafika 2002).[116].

28 ibid.[125].
} 
be concluded based on the opinion of Vos that the division of negligence according to van Hammel is not inaccurate because both are one and the same related part. The principle of no criminal without error is a principle that is very influential in criminal law, especially in criminal conviction or punishment. The position of error in the responsibility of criminal law which is very important until now is not supported by the product of legislation as a legal basis for its validity. Dennis in the book The Critical Condition of Criminal Law quoted by Freeman said that most of the legislation in criminal law has been released to specific offenses. General principles of criminal liability are largely still the work of the judges. ${ }^{29}$ Dennis's view is very reasonable because in the Indonesian criminal law regulations in the Special Act most of it does not determine the form of error or requires the existence of an error of the perpetrators. The legislators are more focused on formulating criminal acts without paying attention to their mistakes so that the compatibility between the act and the formulation of the law is considered sufficient to prove the criminal act. Changes in the direction of the formation of legislation that does not regulate the form of wrongdoing by the perpetrators does not eliminate the mistakes of the perpetrators because there are still many criminal formulations which do not contain the form of wrongdoing by the perpetrators but implicitly require that the acts must be done intentionally or negligently. Much like the formulation of Article 2 and Article 3 of the PTPK Act that does not provide a clear formulation of the form of mistake a perpetrator can conduct. However, the wording of Article 2 and Article 3 of UU PTPK proves that a mistake must be in the form of intentionality. This is because there would be no person that, by its intent, conducts something out of pure negligence. Furthermore, there would be no one who commits negligence in order to benefit another person or corporation.

In addition to statutory regulations that do not regulate or formulate errors in criminal provisions, in the development of criminal law, the principle of no criminal without error is not absolutely valid because for certain criminal acts the

\footnotetext{
${ }^{29}$ Michael Freeman, Law and Opinion at The End of Twentieth Century (Oxford University Press 1997).[230].
} 
perpetrators' mistakes do not need to be proven through absolute accountability. Strict liability can be interpreted that the maker can already be convicted if he has committed acts as formulated in the law without considering the inner attitude of a person. ${ }^{30}$ The fulfillment of an element within a criminal act is enough to be used as the basis for criminal responsibility, without the need to prove the existence of fault from the perpetrator. The principle of responsibility is absolute in England's judicial system and it is only invoked in issues that involve a violation of public order or general welfare. ${ }^{31}$ Different from the criminal judicial system in Indonesia, strict liability is implemented for grave violations or cases involving the loss of life. Aside from being implemented in specific cases, strict liability or absolute responsibility is applied in cases regarding violations of corporation. ${ }^{32}$ This absolute responsibility in charges against corporations is necessary due to the fact that corporate organs can commit crimes on behalf of their corporation. Absolute responsibility can also be invoked for responsibility of corporations for criminal acts if that corporation obtains the benefits from the criminal act. There exists three premises that can be the basis of strict liability in criminal law, according to L.B. Curzon, which are essential to ensure the implementation of important rules needed to maintain public welfare; proving the existence of fault is very difficult in cases regarding the violation of public welfare. ${ }^{33}$

Romli Atmasasmita stated the purpose of the law in general, specifically criminal law is peace and expediency for hostile parties (perpetrators with victims and victims' families) as well as the surrounding community as the main objective while order, certainty and justice are secondary or alternative objectives. Furthermore, Romli Atmasasmita stated the principle of a new criminal law that

${ }^{30}$ Barda Nawawi Arief, 'Fungsionalisasi Hukum Pidana Dalam Menanggulangi Kejahatan Ekonomi, Makalah Seminar Nasional Peranan Hukum Pidana Dalam Menunjang Kebijakan Ekonomi' (1990).[28].

${ }^{31}$ Romli Atmasasmita, Asas-Asas Perbandingan Hukum Pidana, (Yayasan Lembaga Bantuan Hukum Indonesia 1989).[91].

${ }^{32}$ Chairul Huda, Dari Tiada Pidana Tanpa Kesalahan Menuju Kepada Tiada Pertanggungjawaban Pidana Tanpa Kesalahan (Tinjauan Kritis Terhadap Teori Pemisahan Tindak Pidana Dan Pertanggungjawaban Pidana) (Cetakan Ke, Kencana Prenada 2011).[50].

${ }^{33}$ Hamzah Hatrik (n 21).Op.Cit.[13]. 
is no criminal without error, no error without usefulness as an effort to overcome the problem of inefficiency and infectivity of criminal law. ${ }^{34}$ Furthermore, Romli Atmasasmita stated the principle of a new criminal law that is no criminal without error, no error without usefulness as an effort to overcome the problem of inefficiency and infectivity of criminal law. ${ }^{35}$ This theory is the development of no criminal without error where Romli Atmasasmita thinks that every mistake will cause criminal consequences, but the crime is not necessarily beneficial for the person making the mistake, so the imposition of a crime against the person making a mistake must be based on expediency. If a criminal is not beneficial to the person who makes a mistake in a criminal offense then he cannot be convicted. The principle of criminal liability without error can be applied to malicious agreements to commit criminal acts of corruption as a form of extraordinary and beneficial efforts to prevent corruption. The application of criminal liability without error must still pay attention to the other elements of criminal conspiracy.

\section{The Criminal Conspirocy in Criminal Law as IUS Contituen Dum}

The principle of absolute responsibility in cases of criminal conspiracy to commit corruption is applied in relation to making agreements between two or more people. The crime of criminal conspiracy requires the meetings of minds or mens rea (guilty mind) because there must be a common will or intention among people who engage in evil consensus. The condition that there is an equal will in making a bad deal to commit a criminal act of corruption can be done because the agreement is in accordance with the wishes of the parties or one of the parties is forced to make the agreement. In this connection, the agreement to commit a criminal act of corruption uses the principle of presumption of guilt in which the agreement between two or more people is deemed based on free will in accordance with the wishes of the parties. The application of the principle of presumption of guilt and absolute responsibility in proving the existence of a common will in a

\footnotetext{
${ }^{34}$ Romli Atmasasmita (n 31).Op.Cit.[27].

35 ibid.[75].
} 
criminal conspiracy is because the public prosecutor will have difficulty in proving whether in making direct and indirect agreements there is coercion or voluntary.

To prove is the same as providing evidence, to conduct something as the trust, execute it, to mark it, showcase and convince. ${ }^{36}$ Evidence is a proses, method, effort to showcase the truth of events in a court proceedings. ${ }^{37}$ M. Yahya Harahap ${ }^{38}$ elaborates that evidence is the requirements that regulates the methods, referring to applicable regulations, to prove the defendant guilty during a court proceeding. The conclusion that can be drawn from this is that evidentiary process is a process conducted during a court proceeding, that determines whether or not a person can be charged with a criminal claim or be free from the charges presented because there exists enough evidence to provide a judgement or the defendant is proven to not have committed a criminal act. ${ }^{39}$

Article 66 of the KUHAP elaborates that the defendant is not provided with the burden of proof and that the burden of proof is limited under the PTPK Act, covering only the wealth of the defendant or suspect. Whereas to prove the existence of a wrongful act, the burden of proof lies to the public prosecutor in accordance with Article 66 of the KUHAP. The public prosecutor burden of proof is limited in this case, whether or not the formulation of a direct or indirect agreement indeed includes an element of force must also be asserted as a preventive measure towards corruption. Thus, the application of the presumption of innocence and absolute responsibility can be justified. The application of the principle of presumption of innocence in a proceeding relates to the application of limited evidentiary system. The principle of reversing the burden of proof in the Indonesian criminal law system is well-known in the corruption cases, cases of money laundering and consumer protection. ${ }^{40}$ Indriyanto Seno Adji elaborates that the principle of reversing the burden of proof

\footnotetext{
${ }^{36}$ Soedirjo, Jaksa Dan Hukum Dalam Proses Pidana (Akademikia Pressindo 1985).[47].

${ }^{37}$ Kamus Besar Bahasa Indonesia, Pusat Bahasa Departemen Pendidikan Nasional (Ketiga, Balai Pustaka 2005).[172].

${ }_{38}$ M. Yahya Harahap, Pembahasan Permasalahan Dan Penerapan KUHAP; Pemeriksaan Sidang Pengadilan, Banding, Kasasi Dan Peninjauan Kembali (Sinar Grafika 2005).[252].

39 Lilik Mulyadi, Pembalikan Beban Pembuktian Tindak Pidana Korupsi (Alumni 2007).[76].

40 ibid.[103].
} 
is a system whereby outside theoretical normalities the burden of proof in universal criminal procedural law will still be given to the public prosecutor. This is reversed only in cases of the protection and appreciation of human rights, especially the rights of the defendant. ${ }^{41}$ The reversal of the burden of proof within the PTPK Act is limited only to the wealth of the defendant, whereas for the criminal act itself the burden of proof still lies on the prosecutor. The existence of this principle within the PTPK Act can be broaden with regards to criminal conspiracy due to the fact that law enforcers face limitations and difficulties in proving that the agreement element in a criminal conspiracy, such as the case of Syahril Johan.

The application of the principle of presumption of guiltand absolute responsibility does not eliminate the right of the suspect or defendant to prove otherwise as part of the defense. The suspect or defendant is given the right and opportunity to prove whether the agreement in the evil agreement is based on the same will or because there is coercion. If there is coercion in making the agreement, the criminal threat against the perpetrator must be reduced by taking into account the condition or condition of the perpetrator when making a bad consensus. Reduction of punishment in malicious agreements due to coercion from other parties that made the agreement implemented in China even liberation but liberation is not an option. Those who are forced have the opportunity to inform law enforcement officials about coercion to make agreements in an evil agreement to commit criminal acts of corruption.

Lamintang elaborates that criminal conspiracy has been asserted as two or more persons who have reached an agreement to commit a criminal act. ${ }^{42}$ Wirjono Prodjodikoro elaborates that criminal conspiracy is special because when two or more persons have reached an agreement to commit a criminal act, they must already be punished as if they have committed the act. ${ }^{43}$ Further, Wirjono

\footnotetext{
${ }^{41}$ Indriyanto Seno Adji, Korupsi Dan Pembalikan Beban Pembuktian (Kantor Pengacara dan Konsultasi Hukum Prof Oemar Seno Adji, SH \& Rekan 2006).[132]

${ }_{42}$ P.A.F. Lamintang, Delik-Delik Khusus Kejahatan-Kejahatan Terhadap Kepentingan Hukum Negara (Sinar Baru 1986).[90].

${ }^{43}$ Wirjono Prodjodikoro, Tindak-Tindak Pidana Tertentu Di Indonesia (Ketiga, Refika Aditama 2012).[201].
} 
Prodjodikoro also elaborates that within criminal conspiracy there exists no attempt or even preparatory acts. ${ }^{44}$ This is what makes the act of criminal conspiracy really special due to the fact that there exists no attempt or preparation of such acts. The existence of two crucial elements in criminal conspiracy which is the existence of an agreement and two or more persons to commit the crime.

There are different interpretations about when the elements of evil consensus are met, namely whether when two or more people reach an agreement to commit a crime can be considered as a consensus or whether there must be a preliminary action to assess the occurrence of evil consensus. R. Soesilo said that all the discussions to enter into an agreement were not yet included in the definition of criminal conspiracy. ${ }^{45}$ There exists two views regarding the development of the criminal act of criminal conspiracy, the first being the one that states that the meeting of minds or adjustment of wills between the parties required to conduct a criminal conspiracy is enough to state that the criminal act has occurred. Another perspective states that the meeting of minds is not enough to state that the crime has occurred due to the fact that the meeting of minds is merely an internal act. The party who rejects the agreement as the basis for criminal conviction is based on the thought of inner attitudes in criminal law that cannot be convicted because the punishment must be based on an intentional or negligent mistake. In addition, criminal law upholds the principle of geen straft zonder schuld or no crime without error. If criminal conspiracy is equated with a meeting of minds, then it is synonymous with punishing the will or intention (mens rea) only. The construction of such a law which governs this act is very dangerous and can cause a person's constitutional rights to be taken away. The crime of criminal conspiracy is different from the criminal act of trial (poging) regulated in Article 53 of the Criminal Code. The criminal act of probation must fulfill three elements, namely the intention, the beginning of the implementation and the act does not become finished outside the will of

\footnotetext{
${ }^{4}$ ibid.

${ }^{45}$ R. Soesilo, Kitab Undang-Undang Hukum Pidana (KUHP) Serta Komentar-Komentarnya Lengkap Pasal Demi Pasal (2014).[97].
} 
the perpetrator. However, with the construction of the criminal law of criminal agreement which is in force today, the intention to commit an evil agreement can be punished. Pursuant to Article 110 paragraph (1) of the Criminal Code, crimes that can be associated with criminal conspiracy are only related to crimes regulated in Articles 104, 106, 107 and 108 of the Criminal Code or for crimes relating to the president and vice president, state security and treason.

Criminal conspiracy in Dutch criminal law consists of 3 (three) elements, namely an agreement between at least two parties, committing a substantive serious violation, and where the parties have a dual purpose, namely an agreement to commit as well as an intention to commit a substantive violation. ${ }^{46}$ The violation is considered to be finished as soon as the parties have made an agreement to commit a serious crime and does not require any other action as a continuation of the evil agreement because it is considered to make it difficult to prove the evil agreement. ${ }^{47}$ The Minister of Justice during the parliamentary debate on the 2004 Terrorist Abuse Act put forward the making of an agreement or agreement as actus reus of the parties in an criminal conspiracy. ${ }^{48}$ Referring to the view of the Dutch Minister of Justice above, in criminal acts fulfills the elements of mens rea and actus reus, that is, mens rea exists when he prepares or negotiates an agreement to commit a crime whereas actus reus exists when he commits or makes an agreement as a form an embodiment of the meeting of minds. Thus the existence of an agreement to commit a crime is the basis for the fulfillment of the elements of criminal conspiracy.

Referring to the principle which states that there exists no criminal act without fault, whereby in some cases can be deterred through the application of absolute responsibility or conviction without crime and the principle of no wrongful act without benefit that is elaborated by Romli Atmasasmita, a new concept of criminal conspiracy can occur. Bearing in mind the practices and characteristics of corruption in Article 2,

${ }^{46}$ Caroline M. Pelser, 'Preparations to Commit A Crime The Dutch Approach to Inchoate Offences' (2008) 4 Utrecht Law Review.[76].

47 ibid.

48 ibid.[77]. 
Article 3, Article 5-Article 14 of the PTPK Act. Article 2, Article 3, Article 5-Article 14 of the PTPK Act is a criminal act that is qualified as delicta propria. Delicta Propria is a delict that can only be done by certain people. As a criminal act of corruption in Article 3 of the PTPK Act which requires an act of abusing the authority, opportunity or means available to him because of his position or position for the occurrence of the crime. Certain qualities can be in the form of position, authority, profession, occupation, or other qualities related to criminal acts of corruption as referred to in Article 2, Article 3, Article 5, up to Article 14 of the PTPK Act. Thus the meaning or concept of evil agreement in the PTPK Law as ius constituendum is an agreement to commit a criminal act of corruption occurs if two or more people who have quality and interests, agree to commit a criminal act of corruption as referred to in Article 2, Article 3, Article 5, up to Article 13 of the PTPK Act.

The quality referred to in the formulation of an agreement to commit a criminal act of corruption above relates to two or more people who made an agreement to commit a criminal act of corruption must have the ability to commit an agreed corruption act. The ability referred to in this case relates to the position or position of the parties in agreement and financial or influence to be able to continue such agreement. If the perpetrators do not have the ability, then the agreement does not meet the qualifications of the conspiracy because without any law enforcement, the parties will not be able to commit the crime of corruption agreed upon. For example, $\mathrm{A}$ and $\mathrm{B}$ agree to conduct auction arrangements for procurement of government goods/services but A and B do not have or qualify to be bidders and do not have the financial power or influence to arrange auctions. Based on the illustration above, A and $\mathrm{B}$ cannot be convicted based on a criminal conspiracy because A and B will not be able to commit an agreed crime because they lack quality. Quality in this case does not have to be the same because the main thing is that the agreement reached is carried out by people who have the ability to commit criminal acts of corruption. As for the interest in question, the agreement made is indeed appropriate and is related to the desires and goals of the parties making the agreement. Thus, the elements in the agreement to commit criminal acts of corruption in the future are: 
a. Two persons or more;

b. Have quality and interest;

c. Agreement;

d. Conduct the criminal act of corruption, as mentioned in Article 2, Article 3, Article 5 until Article 13 of the PTPK Act.

\section{Conclusion}

Agreements to commit certain criminal acts are an extension of criminal liability and criminal offenses as well as reasons for aggravating maximum criminal threats. The expansion of criminal liability in evil consensus appears in the conditions of evil consensus when two or more people agree to commit a crime. The expansion of criminal acts is seen in the criminal provisions, namely in the Criminal Code and special laws regulating criminal agreements to carry out criminal acts as referred to in the relevant criminal rules so that criminal acts of criminal agreement stand on their own and have their own characteristics from the main criminal acts. The main criminal provisions apply if the criminal act has been completed or all the elements required in the criminal act are fulfilled while in the evil agreement does not require the completion of the criminal act. The concept of evil agreement in the PTPK Law as ius constituendum is a criminal conspiracy to commit the criminal act of corruption where two or more persons have the qualifications and the interest, have agreed to commit the criminal act of corruption as mentioned in Article 2, Article 3, Article 5 and Article 13 of the PTPK Act.

\section{Bibliography}

A.Z. Abidin, Asas-Asas Hukum Pidana Bagian Pertama (Alumni 1987).

Andi Hamzah, Hukum Acara Pidana Indonesia (Sinar Grafika 2002).

Barda Nawawi Arief, 'Fungsionalisasi Hukum Pidana Dalam Menanggulangi Kejahatan Ekonomi, Makalah Seminar Nasional Peranan Hukum Pidana Dalam Menunjang Kebijakan Ekonomi' (1990).

Caroline M. Pelser, 'Preparations to Commit A Crime The Dutch Approach to Inchoate Offences' (2008) 4 Utrecht Law Review. 
Chairul Huda, Dari Tiada Pidana Tanpa Kesalahan Menuju Kepada Tiada Pertanggungjawaban Pidana Tanpa Kesalahan (Tinjauan Kritis Terhadap Teori Pemisahan Tindak Pidana Dan Pertanggungjawaban Pidana) (Cetakan Ke, Kencana Prenada 2011).

D. Schaffmeister NK dan EPS, Hukum Pidana (ketiga, Citra Aditya Bakti 2011).

Departemen Kehakiman RI, Kitab Undang-Undang Hukum Pidana Terjemahan Resmi Dari Wetboek van Strafrecht (WvS) (Sinar Harapan 1983).

E. Utrecht, Rangkaian Sari Kuliah Hukum Pidana I (Penerbitan Universitas 1958)

—_, Rangkaian Seri Kuliah Hukum Pidana I "Suatu Pengantar Hukum Pidana Untuk Tingkat Pelajaran Sarjana Muda Hukum Suatu Pembahasan Pelajaran Hukum (Universitas Padjajaran 1958).

Hamzah Hatrik, Asas Pertanggungjawaban Pidana Korporasi Dalam Hukum Pidana Indonesia (Strict Liability Dan Vicarious Liability) (Raja Grafindo Persada 1996).

Indriyanto Seno Adji, Korupsi Dan Pembalikan Beban Pembuktian (Kantor Pengacara dan Konsultasi Hukum Prof Oemar Seno Adji, SH \& Rekan 2006).

Kamus Besar Bahasa Indonesia, Pusat Bahasa Departemen Pendidikan Nasional (Ketiga, Balai Pustaka 2005).

Lilik Mulyadi, Pembalikan Beban Pembuktian Tindak Pidana Korupsi (Alumni 2007).

M. Yahya Harahap, Pembahasan Permasalahan Dan Penerapan KUHAP; Pemeriksaan Sidang Pengadilan, Banding, Kasasi Dan Peninjauan Kembali (Sinar Grafika 2005).

Michael Freeman, Law and Opinion at The End of Twentieth Century (Oxford University Press 1997).

Moeljatno, Asas-Asas Hukum Pidana (Rineka Cipta 2008).

Muhammad Ainul Syamsu, Pergeseran Turut Serta Melakukan Dalam Ajaran Penyertaan, Telaah Kritis Berdasarkan Teori Pemisahan Tindak Pidana Dan Pertanggungjawaban Pidana (Pertama, Kencana Prenada 2014).

P.A.F. Lamintang, Delik-Delik Khusus Kejahatan-Kejahatan Terhadap Kepentingan Hukum Negara (Sinar Baru 1986).

__, Dasar-Dasar Hukum Pidana Indonesia (Citra Aditya Bakti 2011). 
R. Soesilo, Kitab Undang-Undang Hukum Pidana (KUHP) Serta KomentarKomentarnya Lengkap Pasal Demi Pasal (2014).

Roeslan Saleh, Perbuatan Pidana Dan Pertanggung Jawaban Pidana (Centra 1968).

Romli Atmasasmita, Asas-Asas Perbandingan Hukum Pidana, (Yayasan Lembaga Bantuan Hukum Indonesia 1989).

—_, Rekonstruksi Asas Tiada Pidana Tanpa Kesalahan (Geen Straft Zonder Schuld) (Gramedia Pustaka Utama 2017).

Rudy Hendra Pakpahan and Aras Firdaus, 'Pembaharuan Kebijakan Hukum Asset Recovery: Antara Ius Constitutum Dan Ius Constituendum' (2019) 16 Jurnal Legislasi Indonesia $<$ http://e-jurnal.peraturan.go.id/index.php/jli/article/ view/514>.

Satochid Kartanegara, Hukum Pidana Kumpulan-Kumpulan Kuliah, Balai Lektur Mahasiswa, (Balai Lektur Mahasiswa 1998).

Soedirjo, Jaksa Dan Hukum Dalam Proses Pidana (Akademikia Pressindo 1985).

Stanford H. Kadish and Monrad G. Paulsen, Criminal Law and Its Process, Cases, and Materials (Toronto, Little Brown and Company 1975).

Sudarto, Hukum Pidana I, Badan Penyediaan Bahan-Bahan Kuliah FH-UNDIP (Universitas Diponegoro).

Sudikno Mertokusumo, 'Sistem Peradilan Di Indonesia' (1997) 6 Jurnal Hukum Ius Quia Iustum <https://journal.uii.ac.id/IUSTUM/article/view/6927>.

Tari Endah Guntari and Rizanizarli, 'Penerapan Uang Pengganti Sebagai Pidana Tambahan Terhadap Terpidana Korupsi' (2017) 1 Jurnal Ilmiah Mahasiswa Bidang Hukum Pidana, Fakultas Hukum Universitas Syiah Kuala.

William Wilson, Criminal Law, Doctrine and Theory (Logman 2003).

Wirjono Prodjodikoro, Tindak-Tindak Pidana Tertentu Di Indonesia (Ketiga, Refika Aditama 2012).

HOW TO CITE: Yulianto, 'The Concept Of Conspiring To Corrupt In Criminal Law As Ius Contituendum' (2020) 35 Yuridika. 